\title{
An Analysis of Local and Immigrant Entrepreneurs in South Africa's SME Sector
}

\author{
Dr Simon Radipere \\ Department of Business Management, University of South Africa, South Africa \\ radipns@unisa.ac.za \\ Dr Shepherd Dhliwayo \\ Department of Business Management University of Johannesburg, South Africa \\ sdhliwayo@uj.ac.za
}

\section{Doi:10.5901/mjss.2014.v5n9p189}

\section{Abstract}

This study was undertaken to investigate the motivation, intention, culture and business performance of South African and immigrant entrepreneurs in the small, medium and micro enterprises (SMMEs) sector. The effect of these factors on entrepreneurship was assessed. This was necessitated by the continued low competitive ranking and poor performance of South African entrepreneurs compared to other nationals in studies such as the GEM reports. Questionnaire was used to collect data through interviewer and administrated and a self-administered survey from 500 SMMEs and $93 \%$ questionnaires were returned. The results of the study showed that there is no significant difference between motivation to start a business and the origin of the sampled SMME owners in the retail industry of Gauteng province. The results show that a significant difference does not exist between the owner's origin and culture. This implies that the variable "origin of owner(s)" is not a determining factor in one's culture to start a business. Results also showed that there is no significant difference between the mean scores of the origin of the owner and business performance. This implies that the performance of business is not informed by whether the owner is local or foreign.

Keywords: immigrant entrepreneurs; entrepreneurial intention; culture; business performance; motivation.

\section{Introduction}

Entrepreneurship is seen as the driving force behind economic development. Some authors, such as Morris, Schindehutte and Lesser (2002) argue that entrepreneurship is a fundamental value-driven activity. Rogerson (2003) argue that personal values seem to have important implications not only for the decision to pursue entrepreneurship, but also the way in which the entrepreneur approaches a venture. Morris et al, (2002) highlight that values reflect the entrepreneur's conscious view of himself or herself. Some studies in Africa (Nwanko 2005) conclude that psychological variables and race and ethnicity are important predictors of entrepreneurial activity. It is important to explore how much influence a common set of values has on entrepreneurial development.

As the pace of change continues to accelerate globally, the success of community enterprises depends on the innovation of entrepreneurs. Yet the Global Entrepreneurship Monitor (GEM 2010) reported South Africa as performing low (9.1\%) in entrepreneurship, with total entrepreneurial activity (TEA) below the average of comparable economies around the world. This means that South Africa has the smallest proportion of entrepreneurs compared with other developing countries. South Africa's low ranking in global competitiveness is a source of national concern and this feeds the debate around the factors that impact on entrepreneurial performance.

Rogerson (1997) reports that since 1994, there has been a growing movement of foreign migrants and refugees to South Africa. These migrants reportedly come primarily from South Africa's traditional labour supply areas, including many Southern African Development Community (SADC) countries. In South Africa there have been intermittent but persistent, and at times fatal, attacks on non-South African entrepreneurs. Many traders have been killed by groups purporting to represent unemployed people in South Africa (Nkealah 2012; Human Science Research Council 2008). These people complain that foreigners are taking their jobs and businesses, for example the taxi industry (Nkealah 2012). The apparently strong business establishment of the foreign ethnic part of South Africa's economy presents a template of success for immigrant entrepreneurship.

The paper attempts to examine whether immigrant entrepreneurs perform better than local entrepreneurs. It will 
establish whether a set of entrepreneurial start-up factors (motivation, culture, intention and business performance) affect the local and immigrant entrepreneurs the same way.

In different countries certain groups of immigrants have levels of self-employment exceeding the national average. The level of self-employment is, for example, higher among Asians and SADC immigrants in South Africa than among nationals (Mthembu-Mahanyele 2002). Most of these businesses seem successful when we compare them with local businesses. Their success is realised in terms of market growth or increases in business size.

There is a need to determine the successful business strategies used by immigrant entrepreneurs which locals do not use. The fact that more immigrants than locals seem to start businesses is quite baffling. Are immigrant and local entrepreneurs motivated differently in starting and managing businesses?

This paper is structured in the following manner: section 1 presented the research background and aim of the study. The next section, 2 presents literature review on South Africa and immigrant entrepreneurship. The section further elaborates the constructs used in this study and outlines proposed hypotheses. Section 3 presents the research methodology and finally, section 4 concludes the paper with a discussion of the findings and implications for practitioners.

\section{Literature Review}

Entrepreneurship plays an important role in supporting economic activities in the country by creating jobs and by contributing to country's gross domestic product. Entrepreneurial activities create country's wealth and reduce people's dependence on government for providing jobs. When entrepreneurial activities are low, this then presents a big challenge and there will therefore need to understand why. The first section of this literature review paints the picture of entrepreneurship in South Africa

\subsection{Entrepreneurship in South Africa}

Measuring Total Entrepreneurial Activity (TEA) is one of the major methods the GEM uses to assess entrepreneurship in countries. When comparing South Africa's economy with those of other countries, its data present a worrying pattern. In 2003 South Africa's number of entrepreneurs as a percentage of the total labour force was 4.3, which is lower than the average percentage of 8.8 for all participating countries (GEM 2003). In 2010 South Africa ranked 27th out of 59 countries, with a TEA rate of $8.9 \%$ - below the average (11.9\%) of all participating countries. In all GEM's surveys, South Africa's performance in terms of relative position to other countries has consistently been below the median. South Africa's 2010 TEA rate of $8.9 \%$ was a significant improvement on its 2009 TEA rate of 5.9\%; however, it was still below the average for efficiency-driven economies (11.7\%) and significantly below the average for all middle to low-income countries (15.6\%). Bosma and Levie (2009) argue that economic development is not the only factor that determines entrepreneurship rates; entrepreneurial attitudes and perceptions also play an important role in creating an entrepreneurial culture. On the indicators of entrepreneurial attitudes and perception in efficiency-driven economies, South Africa also scored below average in 2010 (GEM 2010). The country ranked in the bottom third of all efficiencydriven economies in terms of both perceived capabilities and entrepreneurial intentions. Von Broembscen, Wood and Herrington (2005) note that even though the TEA rate provides a quantitative assessment of entrepreneurial activity, it does not provide much information about the quality of entrepreneurship.

The important factor to look at is the proportion of start-ups or new companies to established businesses. South Africa's nascent entrepreneurial activity (that is, in new businesses and established businesses) is rated at $5.1 \%$, which is below the GEM average of $6.4 \%$ and the average of $6.7 \%$ for efficiency-driven economies. The country achieved $3.9 \%$ in terms of new company activity, which is lower than the average of $5.9 \%$ for all GEM countries and $5.2 \%$ for all efficiencydriven countries. This and other figures showing a lower than average level of entrepreneurial activity in South Africa present challenges to all role players (government, the private sector and educators) for getting programmes that encourage entrepreneurship off the ground so that this gap can be decreased (Groenewald, Mitchell, Nayager, Van Zyl, Visser, Train \& Emanuel. 2006).

\subsection{Immigrant entrepreneurship in South Africa}

The increasing number of immigrant-owned businesses in Gauteng leads to increased attention on immigrant entrepreneurship. This is a particular point of interest in efforts to explain the variations in the level of entrepreneurial activity between different groups of entrepreneurs. In different countries, we find certain groups of immigrants who have levels of self-employment exceeding the national average. For example, the level of self-employment is the highest 
among Asians and SADC immigrants in South Africa (Mthembu-Mahanyele 2002). Most immigrants suffer prolonged unemployment and experience difficulties in getting into the labour market. For many, this is the reason why they engage in small business. Immigrant business owners have increased in numbers compared to a decade before. According to Statistics South Africa (StatsSA 2010) immigrant businesses make up about $2.5 \%$ of the total number of businesses and the immigrant population is about $3 \%$ of the total population. Immigrant businesses are estimated to account for about $2 \%$ of new business start-ups.

In Johannesburg and Tshwane's inner cities, over 50\% of the participants in clothing production are from West Africa (Rogerson 1997). Other West and Central Africans gravitate towards operating restaurants and night clubs. These businesses tend to specialise in supplying food, music and clothes from home countries, confirming the importance of networks in directing forms of entrepreneurship. Peberdy (2009) indicates that immigrant entrepreneurs in car repair and maintenance tend to come from Zimbabwe and Mozambique, while those producing wire products and curios tend to come from Malawi and Zimbabwe. Many Zimbabweans and Mozambicans learned their trades in paid employment before becoming self-employed. Generally, these immigrants' businesses are run by single, young, male entrepreneurs who work long hours (64 hours per week) or six days a week. Their employees work similar hours (Katalitanyi and Visser 2010).

\subsection{Business start-up factors}

There are a number of business start-up factors such as, motivation, entrepreneurial intention, culture and business performance. These are going to be discussed showing if they impact immigrant and local entrepreneurs in the same way.

\subsubsection{Motivation}

The study of motivation in the context of entrepreneurship in terms of basic concepts like achievement need, risk taking, tolerance of ambiguity and locus of control has had mixed results. Motivation of entrepreneurs does influence the direction and nature of business ventures. Motivation is what drives people to behave in certain ways. People are not always aware of what motivates them. They behave in ways that seem right under the circumstances. Kuratko, Morris and Covin (2008) propose a model of entrepreneurial motivation and postulates that the desire to create a new venture and willingness to sustain it relate to the entrepreneur's motivation. These authors recognise personal characteristics as one of the motivational factors for entrepreneurship. There are some other reasons or forces that cause an individual to become an entrepreneur. These reasons or forces can be classified as either opportunity (pull factors) or necessity (push factors) reasons for entrepreneurship. The pull factors are those factors that encourage people in traditional positions to leave their current jobs to become entrepreneurs. The push factors are those factors that encourage people to become entrepreneurs because traditional jobs are less attractive and they do not have any other career choice or option (Nieman \& Nieuwenhuizen 2009).

If the individual is starting a business because he has no other way of earning a living, then this business is referred to as one motivated by necessity. If the individual is starting a business in response to an opportunity in the market place, this business is referred to as one motivated by opportunity. Most immigrants suffer prolonged unemployment and experience difficulties in getting into the labour market. For many, this is the reason why they engage in small business.

According to GEM (2011), between 2006 and 2011 necessity-driven entrepreneurship increased by $22 \%$ among South African entrepreneurs. The GEM 2011 Global Report indicated that the percentage of early-stage entrepreneurs motivated by necessity is $34.8 \%$ while percentage of entrepreneurs motivated by opportunity is $63.4 \%$. This show an increase of South Africans motivated by market opportunity and has better access to employment and government support than the immigrants.

Therefore study suggests that: $\mathrm{H}_{0} 1$ : There is no significant difference between the mean scores of the origin of the owner(s) and motivation to start a business.

\subsubsection{Entrepreneurial intention}

Entrepreneurship is the process of organisational emergence (Van Vuuren and Nieman. 1999). Entrepreneurial intention is crucial in this process and forms the first in a series of actions to organisational founding. The intention towards behaviour can be a strong indicator of that behaviour. The researcher's understanding of the entrepreneurial intention is 
guided by two models: Ajzen's (1991) theory of planned behaviour (TPB) and Shapero's (1984) entrepreneurial event model (SEE). The TPB was developed to explain individual attitudes towards an act, the subjective norm, and perceived behavioural control as antecedents of intention. The SEE was developed to understand entrepreneurial behaviour. Entrepreneurial intention is derived from perceptions of desirability, feasibility and a propensity to act upon opportunities. The TPB and SEE provide comparable interpretations of entrepreneurial intention (Krueger 2000).

Krueger (1993) explains that perceived desirability refers to the degree of attractiveness one finds in starting one's own business and perceived feasibility is the degree of personal competence one perceives in starting a business. This perceived desirability and feasibility is expected to be driven by different factors in local and immigrant entrepreneurs.

Literature shows that there are structural barriers that can prevent immigrants and ethnic minorities from competing with the local residents on an equal basis (Chrysostome. 2010). For example, a study conducted by Vinogradov and Elam (2010) showed that discriminatory wages in the wage employment sector push immigrants toward self-employment. For example, employers tend to under-evaluate their qualification pushing the immigrant to self-employment.

South Africa's rate of entrepreneurial intentions was low at $17.6 \%$ as compared to Brazil of $32.3 \%$ (GEM.2011). Considering South Africa's high unemployment rate (23.9\%), it is highly concerning that so few individuals want to pursue entrepreneurship.

Thus, this study suggests that: $\mathrm{H}_{0} 2$ : There is no difference between the mean scores of the origin of the owner(s) and the intention to start a business.

\subsubsection{Culture}

It is proposed in this study that the cultural backgrounds of entrepreneurs play a significant role in defining the motivation for entrepreneurship. It is the contention of the researchers that motivation for business formation is not universal and that differences in cultural frames of reference would account for differences in the motivation for business formation. According to Hofstede (2001), culture is the interactive aggregate of common characteristics that influence a group's response to their environment. Culture determines the identity of a group in the same way personality determines the identity of an individual.

Culture is how people use values in starting a business and is best understood through the process whereby people incorporate their values into their thinking and behaviour (Samli 2008). Socio-cultural dimensions influence the desirability to start a new business. Hostede's work (2001) has been used extensively in cross-cultural research and has been effective in explaining behavioural differences between people in organisations. Hofstede's framework includes cultural dimensions of individualism-collectivism, uncertainty avoidance, power distance and masculinity-femininity. Most researchers apply this framework in an entrepreneurial context.

Waldinger (2002) points out that cultural factor also contribute towards entrepreneurship. Immigrant entrepreneurship is a continuation of the immigrant's cultural habits in the host country. It stems from the entrepreneurial mentality immigrants carry with them when they immigrate to their host country. Immigrant entrepreneurship can also be explained by means of two other critical factors: the social network and the ethnic niche market(s) in the host country (Chrysostome 2010; Chrysostome \& Arcand 2009). In fact, the factors that are critical for the survival of the immigrant entrepreneur are the pre-migration cultural tradition of entrepreneurial mentality, the ethnic social network and the ethnic niche market (Waldinger, 2002). If this is the case, then cultural differences between locals and immigrants will be expected to influence business start-up differently.

South Africa's rates for societal attitudes towards entrepreneurship increased to 72\% between 2006 and 2011 (GEM.2011). It is encouraging that South Africa has improved its rate but still has a great deal to learn from countries like Brazil with respect to promoting a culture of entrepreneurship.

Therefore the study suggests that:

$\mathrm{H}_{0} 3$ : There is no significant difference between the mean scores of the origin of the owner(s) and culture to start a business.

\subsubsection{Entrepreneurial performance}

Business performance is measured by income, profit, market share, return on investment, number of employees and product lines. For a business to be successful, the entrepreneur must ensure that the business operates as efficiently and effectively as possible. Lerner, Brush and Hisrich (1997) integrated the business owner's performance model with other theoretical perspectives to build a new business performance model which includes human capital, motivation and goals, networks, self-efficacy, culture and entrepreneurial intention. These factors contribute to the performance of business 
reflected through revenue/sales, profitability and number of employees. In different countries certain groups of immigrants have levels of self-employment exceeding the national average. Most of these businesses seem successful when we compare them with local businesses. Their success is realised in terms of market growth or increases in business size (Nkealah 2011). In comparison with other efficiency-driven economies, South Africa appears to perform better on the factors of finance for entrepreneurship and government policies and underperform in the areas of cultural support for entrepreneurship, internal market dynamics, government programmes and physical infrastructure (GEM.2011).

Therefore this study suggests that: $\mathrm{H}_{0} 4$ : There is no significant difference between the mean scores of the origin of the owner(s) and business performance.

\section{Methodology}

The population of the study is SMMEs (Small, Medium and Micro enterprises) in the retail sector of the Gauteng province of South Africa. The researcher uses the brabys.com populations of SMMEs in Gauteng since this organisation is reliable and is the leading registry of SMMEs in the country (GEM 2010). According to Brabys, the population size of SMMEs in the retail industry is 10000 . The study population was therefore based on 10000 SMMEs.

Probability sampling was used to ensure that each member of SMME population is given a known non-zero chance of selection. Simple random sampling was utilised to identify the respondents. This increased accuracy and precision of the sample in representing the characteristics of the population of SMMEs in retail industry in that province.

According to Cooper and Schindler (2008), the sample size that is acceptable is $5 \%$ of the total population. Given this study's estimate of a population of 10000 , it means that the targeted sample was 500 respondents (that is, 10000 entrepreneurs X $0.05=500$ respondents). A structured research instrument (a questionnaire) was used to collect data through self-administration interviews. The investigative questions concerned the following constructs:

Motivation: Respondents were asked to rate the extent certain motivation factors as highlighted by Bandura (1986), influenced them in starting a business. The respondents were asked to state to what extent they agreed with statements on entrepreneurial intention. A four-point Likert scale questions (no extent; little extent, some extent and great extent) were used for each of the 10 questions. The assumption was that local and immigrant entrepreneurs are motivated by different factors to start a business. The researcher wanted to see if this was true and to find out which factors affected which group and to what extent.

Entrepreneurial Intention: The construct "entrepreneurial intention" was based on Krueger's work which tested Shapero's conceptual model. Krueger (1993) tested Shapero's conceptual model of entrepreneurial intention and found that perceived desirability directly and positively influenced entrepreneurial intention. The respondents were asked to state to what extent they agreed with statements on entrepreneurial intention. The factors were grouped into: social network, perceived desirability and perceived feasibility. This section was aimed at establishing the extent to which a person's entrepreneurial intent is influenced not just by self-efficacy but by some human capital factors and social capital factors. These factors inform the intension to start or not to start a business. A five-point Likert scale (strongly disagree, disagree, neutral, agree and strongly agree) was used for each of the three questions with subsections. The assumption was that local and immigrant entrepreneurs intend to start businesses because of different factors. The researcher therefore wanted to see if this was true and to find out which factor affected which group and to what extent.

Culture: The concept of culture as used in this study was based on the work by Hofstede (2001) who posits that human problems and their solutions are limited in number. Hofstede (2001) found statistical evidence for four underlying dimensions of culture, together with their consequences, that reflect a given society's culture in the institutions and behaviour it maintains. The respondents were asked to state the extent to which they agreed with statements on cultural values and dimensions based on Hofstede's concept of culture. The 22 items were aimed at showing the relationship between culture and start-up factors. A five-point Likert scale (strongly disagree, disagree, neutral, agree and strongly agree) were used for each of the five questions with subsections. The assumption was that the decision of local and immigrant entrepreneurs to start a business are based on different cultural factors to start the business. The researcher wanted to see if this was true and to find out which factor affected which group and to what extent.

Business Performance: The assumption that locals and immigrants' business performance might be different was based on Rauch, Lumpkin, Wiklund and Frese's work (2009) in which they argue that social structures like workplace, family and organised social life affect entrepreneurs' access to entrepreneurial opportunities and may influence performance.

The respondents were required to state how their businesses performed in the past five years. The questions were aimed at finding out the extent to which businesses had performed in the following areas: income, profit, market share, return on or investment, number of employees and product line. A five-point Likert scale (decreased significantly, 
decreased a bit, no change, increased a bit and increased significantly) was used for each of the six questions that were asked.

The assumption was that immigrant entrepreneurs perform better than local entrepreneurs in doing business. The researcher therefore wanted to see if this was true and to find out which factor affected which group and to what extent.

\section{Results and Discussions}

Results from the data analysis and the interpretation of the research findings are outlined below.

Some statistical analyses were conducted to determine the validity and reliability of the data. Cronbach's Alpha coefficient was used to assess the consistency and stability of the measurement items. The results of Cronbach alpha test for reliability showed that the data were reliable $(0.673 \%)$ on motivation; culture $(0.782)$; intention $(0.633)$ and entrepreneurial performance (0.902).

\subsection{Descriptive statistics}

The demographic variables for which information was obtained included age, gender and qualification of the owners. Below is the presentation of the demographics of the two respondent samples in the form of tables.

Table 1: Age of the owners

\begin{tabular}{|c|c|c|c|c|}
\hline \multirow{2}{*}{ Owner's Age } & \multicolumn{2}{|c|}{ South African } & \multicolumn{2}{c|}{ Foreign owner } \\
\cline { 2 - 5 } & Count & percentages & Count & percentages \\
\hline 20-29 years & 53 & 24.4 & 65 & 30.5 \\
\cline { 2 - 5 } $30-39$ years & 72 & 33.2 & 90 & 42.3 \\
\cline { 2 - 5 } 40-49 years & 49 & 22.6 & 44 & 20.7 \\
\cline { 2 - 5 } $50-59$ years & 25 & 11.5 & 10 & 4.7 \\
\cline { 2 - 5 } $50+$ years & 18 & 8.3 & 4 & 1.9 \\
\hline
\end{tabular}

There seems to be similarities between the age breakdowns between locals and immigrants as shown by Table 1. It seems that younger entrepreneurs (20-49 age brackets) were more likely to engage in business start-ups than older people (50 years and more). The trend is similar to that found in an overall GEM sample for 2011. South Africans aged between 20 and 49 years are clearly the most entrepreneurially active.

\subsubsection{Gender of the owners}

Of the owner-managers who responded, $62 \%$ were South African males while $67.1 \%$ were foreign males and $37.9 \%$ were South African females while $32.9 \%$ were foreign females. The response rate implies that the small business industry is dominated by males. The GEM (2010) reported that the ratio of male to female participation in entrepreneurial activity varies across the total sample of GEM countries, reflecting differences in culture and customs regarding female participation in the economy. The GEM (2009) reported that in South Africa, men are 1, 5 times more likely to be involved in entrepreneurial activity than women. This is therefore a correct reflection of the situation in South Africa. The 2010 GEM Global Report indicates that for many Latin American countries (Argentina, Chile, Brazil and Peru), the gender gap in total entrepreneurial activity is low, where in Brazil for example, women are more likely to be involved in TEA than men.

Table 2: Education of the owners

\begin{tabular}{|c|c|c|c|c|}
\hline \multirow{2}{*}{ Owner's highest qualification } & \multicolumn{2}{|c|}{ South African } & \multicolumn{2}{c|}{ Foreign owner } \\
\cline { 2 - 5 } & Count & percentages & Count & percentages \\
\hline Grade 1-7 & 7 & 03.2 & 8 & 03.8 \\
\cline { 2 - 5 } Grade 8-12 & 71 & 32.9 & 81 & 40.7 \\
\cline { 2 - 5 } Diploma & 67 & 31.0 & 58 & 27.8 \\
\cline { 2 - 5 } Degree & 51 & 23.6 & 52 & 24.9 \\
\cline { 2 - 5 } & 20 & 09.3 & 6 & 02.9 \\
\hline
\end{tabular}

This shows that most (40.7\%) immigrant business owners operated their businesses with grade 12 (secondary school) as their highest qualification, while only $32.9 \%$ of local owners operated their businesses with grade 12 as their highest 
qualification. A total of $54.6 .9 \%$ of the immigrant owners have Diploma/degree qualification, while compared to 52.7 of the local business owners. There seem to be not much difference when it comes to primary schooling, diplomas and degrees. A slight difference (7.8 \%) exists with regards to secondary education. From the figures in Table 2 above, it can be concluded that education will not affect the performance of these businesses (of immigrants and locals) differently. Locals and foreigner owned SMMEs have more or less the same level of education.

\subsection{The T-test on origin of owner and entrepreneurial variables}

The t-test was used to test the hypotheses that there is no significant difference between the demographic variable (origin of owner) and business start-up factors; motivation, culture, self-efficacy, entrepreneurial intention and performance.

\subsubsection{Origin of owner and motivation}

The question was formulated to establish whether there was a significant difference between the origin of owner and motivation to start a business.

A Levene's test of homogeneity of variance was conducted to test this construct. The construct "motivation" was the only one which was normally distributed hence the Levin's test was conducted.

The Null hypothesis $\mathrm{H}_{0} 1$ is that: There is no significant difference between the mean scores of the origin of the owner and the motivation to start a business.

The results of this test are presented in table 3 below and then analysed and interpreted.

Table 3: The test for equality of means of the owner's origin and motivation

\begin{tabular}{|c|c|c|c|c|c|c|c|c|}
\hline & \multicolumn{2}{|c|}{$\begin{array}{c}\text { Leven's test for equality } \\
\text { of variance }\end{array}$} & \multicolumn{6}{|c|}{ T-test for equality of means } \\
\hline & $\mathrm{F}$ & Sig & $\mathrm{t}$ & df & \begin{tabular}{|c} 
Sig \\
(two-tailed)
\end{tabular} & $\begin{array}{c}\text { Mean } \\
\text { difference }\end{array}$ & $\begin{array}{l}\text { Std. error } \\
\text { difference }\end{array}$ & Upp \\
\hline \begin{tabular}{l|l|} 
Motivation & Equal variance assumed \\
\end{tabular} & 0.267 & 0.605 & -1.460 & 0.432 & 0.145 & -0.821 & 0.562 & \begin{tabular}{|l|l|}
-1.927 & 0.284 \\
\end{tabular} \\
\hline
\end{tabular}

Confidence interval: $95 \% \alpha=0.05$

Table 3 above shows the results for when the assumption of equality of variances was met. The T-tests for equality of means at a 95\% confidence interval of the difference are shown in the table.

There is no statistical significant difference between the mean scores of the origin of the owner and motivation, with p-value of 0.145 which is more than the alpha value of 0.05 at a $95 \%$ confidence level as appears in table 3 above. Applying the $p$-value rule that one should accept the proposition if - and only if - the $p$-value is bigger than the alpha value (0.05), hypothesis $\mathrm{H}_{0} 1$ on motivation is accepted.

It is therefore concluded that there is no significant difference between motivation to start a business and the origin of the sampled SMME owners in the retail industry of Gauteng province. This implies that the motivation to start a business is not determined by whether the owner is local or foreign. People get motivated to start new businesses irrespective of where they come from. People are motivated by pull factors which affect all irrespective of origin.

The T-test was used to test the hypotheses that there is no significant differences between the variable origin of owner and the constructs (culture, self-efficacy, entrepreneurial intention and business performance).

\subsubsection{The origin of the owner}

Table 4: The independent t-test on the origin of the owner(s) and business start-up factors

\begin{tabular}{|c|c|c|c|c|}
\hline & Mann-Whitney U & Wilcoxon W & Z & Asymp. Sig. (two-tailed) \\
\hline Culture & 22587.500 & 46897.500 & -0.729 & 0.466 \\
Entrepreneurial intention & 22261.500 & 46571.500 & -0.980 & 0.327 \\
Performance & 22342.000 & 45778.000 & -0.600 & 0.548 \\
\hline
\end{tabular}

Confidence interval: $95 \%$ a $=0.05$

\subsubsection{Origin of owner and entrepreneurial intention}

Null hypothesis $\mathrm{H}_{0} 2$ stated that: There is no statistical significant difference between the mean scores of the origin of the 
owner and the intention to start a business.

Results show a $p$-value $0.327,>a=0.05$ at a $95 \%$ confidence level (table 4). Applying the $p$-value rule that one should accept the proposition if the p-value is bigger than the alpha value (0.05), the hypothesis $\mathrm{H}_{0} 2$ on entrepreneurial intention is accepted.

It is therefore concluded that there is no significant difference between the mean scores of the origin of the owner and entrepreneurial intention. This implies that the intention of the owner to start a business is not determined by where he or she comes from. People just start businesses irrespective of where they come from. Starting or owning a business is about someone's passion to go into business or the opportunities that the individual would have identified in the market.

\subsubsection{The origin of owner and culture}

Null hypothesis $\mathrm{H}_{03}$ : There is no significant difference between the mean scores of the origin of the owner (entrepreneur) and culture to start a business.

The results show that there is no statistical significant difference between the mean scores of the origin of the owner and culture, as shown by a $p$-value of $0.466,>a=0.05$ in table 4 above. Applying the $p$-value rule that one should accept the proposition if the p-value is bigger than the alpha value (0.05), the hypothesis $\mathrm{H}_{0} 3$ on culture is accepted.

The results show that a significant difference does not exist between the owner's origin and culture. This implies that the variable "origin of owner(s)" is not a determining factor in one's culture to start a business, in other words it implies that one's entrepreneurial culture to start a business is not determined by where one comes from. Cultural factors or dimensions (individualism, masculinity, power distance and uncertainty avoidance) apply equally to both local and foreign owners in starting a business.

\subsubsection{Origin of owner and business performance}

Null hypothesis $\mathrm{H}_{0} 4$ : There is no significant difference between the mean scores of the origin of the owner and business performance.

Results in table 4 above show, $p$-value $0.548,>\alpha=0.05$ at a $95 \%$ confidence level. Applying the $p$-value rule that one should accept the proposition if the p-value is bigger than the alpha value (0.05), the hypothesis $\mathrm{H}_{0} 4$ on business performance is accepted.

It is therefore concluded that there is no significant difference between the mean scores of the origin of the owner and business performance. This implies that the performance of business is not informed by whether the owner is local or foreign. The findings do not support the assertion that foreign owners perform better than the local owners. The results have proven that it is a misconception that foreign-owned businesses perform better than local businesses.

\section{Conclusion and Recommendations}

\subsection{Motivation}

The study shows that there is no significant difference between motivation to start a business and the origin of the sampled SMME owners. There is no excuse for locals not to start their own businesses since they have the same "motivation to start capacity" as foreigners. An economy's capacity for entrepreneurship is determined by individuals' ability and motivation to start businesses, and this may be enhanced by a society's positive perceptions and attitudes about entrepreneurship.

Regular open-days for entrepreneurs at municipal level is suggested, where entrepreneurship champions can address issues on small business ownership. It is also recommended to have a significant media buy-in by local newspapers, radio and/or magazines which can motivate people to participate in entrepreneurship. The media can also increase awareness and involvement in entrepreneurship development in South Africa. Therefore locals should be made to see the foreign owners and their perceived success as role models. It should be made clear that both foreign and locals are driven by the same motives and circumstances. This is the message which the media have to convey so that the foreign businesses are not viewed in a negative light as seems to be the case currently.

\subsection{Entrepreneurial intention}

Intention can be improved through education. Entrepreneurial education is needed to enhance the skills and knowledge of entrepreneurs. It provides the basics of practical business practices. Introducing learners to 
entrepreneurship education at an early stage in the entrepreneurial process can be beneficial as they develop intentions toward starting a new business

\subsection{Culture}

If a society emphasises getting a good education for the purpose of getting a good job, entrepreneurship is viewed as less desirable as a career choice. The nation, together with the government, needs to set the stage to enable a larger part of the population to participate in a more open, more accessible and more widespread culture of innovative entrepreneurship. A culture of entrepreneurship can be created by opening up the field to more groups in society that is not traditionally linked to business. By this, a new influx of values, new patterns of problem solving, new ideas being put into entrepreneurship and new quality of participation in the economic sphere can be expected. The influence of human institutions such as norms, values, morals, family ties and support forms the framework within which individuals can pursue entrepreneurial opportunities.

\subsection{Business performance}

Business performance is measured by income, profit, market share, return on investment, number of employees and product lines. For a business to be successful, the entrepreneur must ensure that the business operates as efficiently and effectively as possible. This is achievable if business owners ensure that their employees are involved in the decisionmaking process of the business and have the capacity and confidence to implement and deliver on strategy. Effective use of employees will increase business performance. It is important that employees are well trained to use the necessary technology (use of computer and internet) and understand the importance of technology in the business. Training should build individual employee self-efficacy and culture within the organisation. Training and development practices can promote entrepreneurial behaviour and encourage high employee participation. Better education brings about better performance.

\subsection{Immigrant entrepreneurs}

Creative immigrant entrepreneurs are able to generate market niches for specific cultural foods to the extent that sometimes ethnic goods even become normal goods, for example Italian pizza and Chinese food. Culturalists think that there are value-laden groups whose skills are cultivated within the family or within the community. These types of skills known as ethnic resources should be transferred to South African entrepreneurs.

Nestorowicz (2011) has identified survival strategies of immigrant entrepreneurs which can be recommended to locals.

Degree of competition: Migrant entrepreneurs usually avoid high degrees of competition and choose markets with lower competition. The lower the degree of competition at a particular place, the higher the chances of success. The higher the entry barriers, the higher the risk. Local entrepreneurs are advised to consider competition before entering a market. Locals tend to go into businesses that they see are doing well and this results in over-trading, for example taverns, spaza shops, shebeens, saloons, cell phone shops, taxi's and internet cafés.

Support network: This is immigrants' relations with relatives, family, kin groups or friends in the receiving region. Migrants prefer to stay close to other family members. The larger the concentration of family and kin in a particular place, the greater the likelihood that new migrants will remain there. Local entrepreneurs must have good relationships with their family as their support group. As literature shows, team work produces good results.

\section{Limitation and Future Research}

Due to localised nature of the study in Gauteng province as well as small sample size involved, the findings of this study cannot be generalised. This becomes a major limitation when the small sample in Gauteng province only is considered against the fact that there are more than 10000 SMMEs in the country. It is suggested that future studies could perhaps use sample from all nine provinces in South Africa to present an overall picture of SMMEs. The study may not apply to big businesses and other sectors, whether started and operated by immigrants or locals.

Further research may look at bigger companies or SMEs in other sectors such as manufacturing or services and other provinces and find the motivation behind the establishment of those companies. 


\section{References}

Rogerson, C.M. 2003. The impact of the South African government's SMME programmes: A ten-year review (1994-2003). Development Southern Africa, 21:765-784.

Nwanko, S. 2005. Characteristics of Black African entrepreneurship in the UK: a pilot study. Journal of Small Businesses and Enterprise Development 12 (1).

Rogerson, CM. 1997. International migration, Immigrant entrepreneurs and South Africa's small enterprise economy. Cape Town: Institute for Democracy in South Africa

Nkealah, N. 2011. Commodifying the female body: Xenophobic Violence in South Africa. Africa Development. Vol. 2: 123-135

Human Science Research Council. 2008. Citizenship, violence and xenophobia in South Africa: Perceptions from South African communities. HSRC. June. 2008

Mthembu-Mahanyele, S. 2002. No title. Address presented at the Annual General Meeting of the National African Federated Chamber of Commerce (NAFCOC), Sun City, South Africa. http://www.housing.gov.za/content/mediadesk/speeches (accessed on 1 October 2006)

Global Entrepreneurship Monitor (GEM). 2003, Report on Higher Expectation Entrepreneurship. www.gemconsortium.org (accessed on 10 May 2007)

Bosma, N \& Levie, J. 2009. Global Entrepreneurship Monitor 2009 Global Report. Scotland: Global Entrepreneurship Research Association

Global Entrepreneurship Monitor (GEM).2010. 2010 Report on Higher Expectation Entrepreneurship.www.gemconsortium.org (accessed on 1 June 2011).

Von Broembsen, M, Wood, E \& Herrington, M. 2005. Global Entrepreneurship Monitor. South African Executive Report. Cape Town: Graduate School of Business, University of Cape Town

Groenewald, M.J, Co, J, Mitchell, B, Nayager, T, Van Zyl, J, Visser, K, Train, W \& Emanuel, B. 2006. Entrepreneurship: Fresh perspectives. Cape Town: Pearson Education.

Statistics South Africa. 2010. Labour force survey (LFS), September 2010. P0210. www.statssa.gov.za (accessed on 02 September 2010)

Perpedy, S. 2001. Imaging immigration: Inclusive identities and exclusive policies in post-1994 South Africa. Africa Today 48(3):15-32

Katalitanyi, V \& Visser, K. 2010. African immigrants in South Africa: Job takers or job creators? South African Journal of Economic and Management Sciences 13(4):376-390

Kuratko, DF, Morris, MH\& Covin, JG. 2008. Corporate innovation and entrepreneurship. $3^{\text {rd }}$ edition. Madison: South-Western Cengage Learning.

Nieman, G \& Nieuwenhuizen, C. 2009. Entrepreneurship: A South African perspective. $2^{\text {nd }}$ Edition. Pretoria. Van Schaik Publishers

Global Entrepreneurship Monitor (GEM).2011. 2011 Report on Higher Expectation Entrepreneurship.www.gemconsortium.org (accessed on 1 July 2012).

Van Vuuren, J.J \& Nieman, G.H. 1999. Entrepreneurship education and training: A model for syllabi/curriculum development. Proceedings of the $45^{\text {th }}$ Conference of the International Council for Small Business (ICSB), Naples.

Ajzen, I. 1991. Theory of planned behaviour. Organisational behaviour and human decision processes. Journal of Development Entrepreneurship 11(3):179-211

Shapero, A. 1984. The entrepreneurial event, in The environment for entrepreneurship, edited by CA Kent. Lexington Mass, Lexington Books:5-9

Krueger, N. 2000. The impact of prior entrepreneurial exposure on perceptions of new venture feasibility and desirability. Journal of Entrepreneurship Theory and Practice 24(3):5-24

Chrysostome, E. 2010. The success factors of necessity immigrant entrepreneurs: In search of a model. Thunderbird International Business Review 52(2):137-152.

Vinogradov, E \& Elam, E. 2010. A process model of venture creation by immigrant entrepreneurs, in The life cycle of new ventures: Emergence, newness and growth, edited by CG Brush, L Kolvereid, O Widding \& R Sorheim. Northampton, Mass: Edward Elgar:109-126

Hofstede, G. 2001. Culture's consequences: Comparing values, behaviour, institutions and organisations across nations. $2^{\text {nd }}$ edition. Thousand Oaks, Calif: Sage

Samli. AC. 2008 .Introduction to entrepreneurship. New York. Coggin College of Business.

Waldinger, R. 2002. Immigrant enterprise: A critique and reformation. Theory and society. Newbury Park: Sage

Chrysostome, E \& Arcand, S. 2009. Survival of necessity immigrant entrepreneurs: An exploratory study. Journal of Comparative International Management 12(2):3-29.

Lerner, M, Brush, C \& Hisrich, R. 1997. Israeli women entrepreneurs: An examination of factors affecting performance. Journal of Business Venturing (12):315-339

Cooper, DR \& Schindler, PS. 2008. Business research methods. 10 $0^{\text {th }}$ edition. Boston: McGraw-Hill Irwin

Rauch, A, Wiklund, J, Lumpkin, GT \& Frese, M. 2009. Entrepreneurial orientation and business performance: An assessment of past research and suggestions for the future. Entrepreneurship Theory and Practice 33(3):761-787

Global Entrepreneurship Monitor (GEM). 2008. 2008 Report on Higher Expectation Entrepreneurship from: www.gemconsortium.org (accessed on 3 June 2009).

Nestorowicz, J. 2011. Know knowns and know unknowns of immigrant self-employment. Warsaw: Centre of Migration Research, University of Warsaw 